\title{
The Expiration of the Ethanol Tax Credit: An Analysis of Costs and Benefits
}

\author{
By Amy Diggs
}

The Volumetric Ethanol Excise Tax Credit expired on December 31, 2011. This costbenefit analysis concludes that without the tax credit, the net benefits will be \$168.1 billion in net present value from 2012 to 2022. The total costs will be $\$ 116.8$ billion, primarily imposed upon ethanol producers and farmers. The benefits, realized through improved environmental conditions and stabilized food prices, will save society a total of $\$ 284.9$ billion. Alternative considerations beyond the scope of this assessment are presented, such as the role of innovation and foreign alternative fuel imports. These considerations will play a significant role in future outcomes from the expiration of the tax credit.

\section{Introduction}

On December 31, 2011, Congress allowed the Volumetric Ethanol Excise Tax Credit (VEETC) to expire. The VEETC was an incentive program designed to increase the amount of ethanol on the market, as an alternative to gasoline. At its time of expiration, VEETC provided a $\$ 0.45$ per gallon tax credit provided to blenders of ethanol with gasoline. The VEETC was enacted in an attempt to obtain social benefits, in the form of lower dependence on foreign oil and environmental improvements, such as decreased greenhouse gas emissions. However, the VEETC failed to facilitate all of these benefits from materializing.

This paper will perform a costbenefit analysis of the VEETC expiration, while maintaining the Renewable Fuel Standard mandates, in order to deter- mine if terminating the tax credit was in the best interest of society. The first section will present the history of ethanol subsidies. The second section will discuss previous and existing federal ethanol subsidies and the rationale behind their creation. The third section will calculate the anticipated costs and benefits of removing VEETC. The fourth section will present other considerations that could affect future results. Finally, the concluding section will summarize the findings and determine the net benefits to society, for allowing VEETC to expire.

\section{History of Ethanol}

Ethanol is a clean-burning, highoctane motor fuel, produced using renewable crop resources, generally sugar or corn. Ethanol has been used in the United States as a motor fuel as early as 1908. At that time, Ford Motor Company created the first Model $\mathrm{T}$, which was designed to run on ethanol, gasoline or a combination of the two. Although ethanol has been around for over a century, the ethanol industry has been unsustainable. Ethanol is the same type of alcohol in alcoholic beverages. During prohibition era, from 1919 to 1933 the production of ethanol was banned in the United States, unless mixed with petroleum. Despite the passage of the Twenty-first Amendment and a resurgence of use during World War II, ethanol was unable to regain its previous standing. (Phaneuf 2007)

In the 1970s, ethanol began to make its comeback. Oil supply disruptions 
in the Middle East and increased environmental awareness raised public interest in alternative fuels. With the increased demand for cars and gasoline, ethanol was identified as a way to lower US dependence on non-renewable, foreign oil. Research concluded that ethanol emits fewer greenhouse gases into the atmosphere when it is burned as fuel, thus reducing the impact on the environment. Despite its benefits to society, the high production costs and comparative low demand for ethanol in relation to gasoline made it an impractical industry. The market disparity caused production firms to face a disadvantage they could not overcome without assistance. As a result, the federal government began providing subsidies for ethanol producers in order to make the market sustainable and to promote the production and use of alternative fuels in the United States. With the allowance of federal subsidies, ethanol production grew from 175 million gallons, in 1980 , to 13.1 billion, in 2011, with a majority of production taking place in Midwestern states, with Iowa, Illinois, Minnesota, and Nebraska being the largest producers (EPI 2011).

\section{Federal Ethanol Subsidies}

Over the last three decades, the federal government established measures to decrease the United States' dependence on foreign oil and improve environmental quality through alternative fuel sources. In 2004, as ethanol appeared to be a viable fuel alternative to replace gasoline, the federal government created the Volumetric Ethanol Excise Tax Credit (VEETC), also known as the blenders' tax credit, under the American Jobs Creation Act. The VEETC provided a $\$ 0.51$ per gallon credit of pure ethanol blended with gasoline to blenders of ethanol, as an incentive to encourage ethanol use in gasoline. The primary beneficiaries of this tax credit were large oil companies. In 2008, the VEETC was renewed under the Farm Bill, reduc-

Table 1: Renewable Fuels Standard Mandates (in billions of gallons).

\begin{tabular}{|l|l|l|l|}
\hline \multicolumn{1}{|c|}{ Year } & \multicolumn{1}{|c|}{$\begin{array}{c}\text { Total Renewable } \\
\text { Fuels }\end{array}$} & $\begin{array}{c}\text { Cap on Corn Starch- } \\
\text { Derived Ethanol }\end{array}$ & $\begin{array}{l}\text { Total Non-Corn } \\
\text { Starch Biofuels }\end{array}$ \\
\hline 2010 & 12.95 & 12.00 & 0.95 \\
\hline 2011 & 13.95 & 12.60 & 1.35 \\
\hline 2012 & 15.20 & 113.20 & 2.00 \\
\hline 2013 & 16.55 & 13.80 & 2.75 \\
\hline 2014 & 18.15 & 14.40 & 13.75 \\
\hline 2015 & 20.50 & 15.00 & 5.50 \\
\hline 2016 & 22.25 & 15.00 & 7.25 \\
\hline 2017 & 24.00 & 15.00 & 9.00 \\
\hline 2018 & 26.00 & 15.00 & 11.00 \\
\hline 2019 & 28.00 & 15.00 & 13.00 \\
\hline 2020 & 30.00 & 15.00 & 15.00 \\
\hline 2021 & 33.00 & 15.00 & 18.00 \\
\hline 2022 & 36.00 & 15.00 & 21.00 \\
\hline
\end{tabular}

Source: Schanef, Randy and Brent Yacobucci (2012) Renwable Fuel Standard (RFS): Overview and Issues. Congressional Research Service; From Eisa (P.L. 110-140), Section 202. 
ing the tax credit to $\$ 0.45$ per gallon of ethanol blended with gasoline. In 2010, the VEETC was renewed for the last time.

To further increase ethanol use, the Renewable Fuel Standard (RFS) program was created in 2005 under the Energy Policy Act, which mandated the minimum volume of renewable fuels to be blended into transportation fuel. The Energy Independence and Security Act of 2007 expanded the RFS by increasing the required volume, to 36 billion gallons by 2022 , see Table 1. The Environmental Protection Agency (EPA) determines the optimal quantity of ethanol to be used in transportation fuel with regards to greenhouse gas emissions over the lifetime of various fuels, from production through consumption.

\section{Cost-Benefit Analysis}

Cost-Benefit Analysis is an assessment of the impact a policy change has on society. It measures the direct and indirect effects of the change by calculating monetary values of the costs and benefits for each affected group, with standing, and comparing the results against an assigned status quo. The purpose of such an analysis is to objectively determine the total net benefits of the policy change and consequently conclude whether or not a policy is efficient.

The expiration of VEETC impacts every American through both positive and negative externalities. Opponents to the expiration of VEETC argue the expiration will have detrimental effects for the biofuel industry, which will spillover as negative externalities for society. Supporters of the expiration claim that if VEETC was allowed, society would suffer from inflated food prices, environmental degradation, and hindering alternative fuel research and innovation. This cost-benefit analysis considers these two perspectives and assesses all possible impacted industries and sectors of society, to determine the impact of the expiration of the VEETC.

The VEETC was a national tax credit; therefore, this cost-benefit analysis will take a national perspective over a ten-year span from 2012 to 2022, comparing it to the status quo of the nation under the VEETC. This period covers the time of the expiration of the VEETC while the RFS is still authorized. Since the VEETC has expired, ex-post timing is necessary to evaluate the costs and benefits. However, because the true impact of the policy's termination remains unknown, costs and benefits will be projected based on prior research and anticipated effects.

\section{Calculation of Costs and Benefits}

The GAO report, Biofuels: Potential Effects and Challenges of Required Increase in Production and Use determined the RFS does not cause the level of ethanol consumption to be higher than without. In this analysis, the RFS volume mandates are taken to be nonbinding, meaning the level of blended ethanol production exceeds the RFS required quantity (GAO 2009). Given this duplicative nature of RFS and VEETC, the expiration of VEETC will result in the quantity of ethanol blended with gasoline to decrease to RFS mandated levels(GAO 2009). This assumption is based on the production levels of ethanol in 2008 equaling 9.5 billion gallons, which exceeds the 9 billion gallon requirement under RFS by 500 million gallons (GAO 2009) .Therefore, it is assumed that the VEETC expiration will cause the quantity of ethanol consumption to decrease and stabilize at the RFS levels through 2022.

As with most taxes, VEETC is assumed to be a transfer between producers and consumers, or those receiving the credit and those paying the credit, respectively. Accordingly, the direct costs and benefits of VEETC in terms of paying for and receipt of the credit will not be included in the calculation of the costs and benefits, as any calculations given would result in zero net benefits.

In order to effectively measure the status quo, 2011 trends in prices, production, and consumption levels will be used to project the status quo under the VEETC through 2022. These trends will 
be further explained in proceeding sections. In order to hold constant the value of money over time, a discount rate of four percent will be used to calculate the present value of future costs and benefits.

\section{Calculation of Costs}

\section{Administrative}

Directly, the expiration of VEETC will not result in any additional administrative costs to enforce or monitor RFS. The EPA currently enforces the mandates and monitors the amount of ethanol blended with gasoline. However, without VEETC, the government will experience a greater demand on agricultural assistance programs. The federal government subsidizes farmers for their crops in response to poor season conditions or a low market price. It has been shown that government agricultural assistance program payments are responsive to change in the demand for agricultural goods, such as corn (Kruse 2007).

The cost to farmers from the VEETC removal can be captured by the loss in profits to corn producers. In the United States, 98 percent of all ethanol was made from corn in 2007 (Kelderman 2007). Because corn makes up nearly all of the ethanol produced in the United States, in this analysis, corn will be assumed to represent the primary input good for ethanol. With a fall in the quantity of ethanol being blended to RFS levels, after the VEETC expires, the demand for ethanol will consequently decrease. Kruse et al. (2007) estimates the increase in the cost of agricultural assistance can be as high as $\$ 570$ million. However, this increase assumes the tax credit is \$0.51. Assuming all else constant, the ratio of $\$ 570$ million per $\$ 0.51$ is the same as a reduced tax credit of $\$ 0.45$ per gallon, to increase agriculture assistance by $\$ 503$ million in 2012. The United States Department of Agriculture (USDA) determined the supply of corn is relatively inelastic at 0.23 in the short run, due to the production process (USDA 2011). Farmers must determine their crop selections at the beginning of the year and plant corn between

Table 2: Category with Identified Costs and Benefits from the expiration of VEETC.

\begin{tabular}{|l|l|l|}
\hline \multicolumn{1}{|c|}{ Category } & \multicolumn{1}{|c|}{ Cost } & \multicolumn{1}{c|}{ Benefits } \\
\hline Administrative & $\begin{array}{l}\text { Monitoring and enforcing RFS } \\
\text { Federal Agriculture Assistance } \\
\text { Programs }\end{array}$ & $\begin{array}{l}\text { IRS VEETC administration costs } \\
\text { Blenders paperwork filing } \\
\text { Federal Food Assistance Pro- } \\
\text { grams }\end{array}$ \\
\hline Production & $\begin{array}{l}\text { Ethanol production } \\
\text { Agriculture production } \\
\text { Employment Changes }\end{array}$ & Alternative biofuel production \\
\hline Consumption & Price of gasoline & Cost of food \\
& Miles per gallon driven & \\
\hline Environmental & $\begin{array}{l}\text { Ethanol Lifecycle greenhouse } \\
\text { gas emissions }\end{array}$ & $\begin{array}{l}\text { Ethanol Lifecycle greenhouse gas } \\
\text { emissions }\end{array}$ \\
\hline Energy Security & N/A & Alternative Fuel Investment \\
\hline
\end{tabular}


March and April. Corn is then harvested September through November. To plant and harvest corn at a large quantity, farmers will have invested in specific equipment. Therefore, when the demand for corn decreases, farmers will lose substantial profits in the first year, but appropriate changes in the long run will minimize these losses. If this increase in agricultural subsidies persists, decreasing by four percent annually due to farmers' ability to transition their fields to grow more profitable crops, removing the VEETC will cost $\$ 4.6$ billion, over ten years.

\section{Production}

The costs of producing ethanol and farming corn will be affected by the removal of VEETC. Under the tax credit, oil companies, who are the primary blenders of ethanol with gasoline, will blend more ethanol than is mandated to receive a larger government payout. In 2010, RFS required 12 billion gallons of renewable fuel to be blended with gasoline. In practice, 13.23 billion gallons were blended, exceeding the amount by 1.23 billion gallons, or ten percent. With the removal of this incentive, oil companies will only blend the optimal amount mandated by RFS, which is below their previous levels; thereby decreasing the quantity of ethanol demanded and reducing the amount of ethanol produced.

The production, distribution, and consumption of ethanol is highly subsidized by hundreds of state and federal programs. Therefore, ethanol producers will only be affected by the reduced demand from blenders because they will continue to receive other government subsidies, such as the biomass crop assistance program, capital grants, tax exemptions for biofuel-related equipment and generic subsidies (Koplow 2009). As a result of high subsidization, the elasticity of supply of ethanol is relatively inelastic to price changes at 0.27 (Du 2008). Kruse determined the price of ethanol would decrease by $\$ 0.29$ with the elimination of a higher tax credit and import tariff (2007). In this analysis, without increased competition from foreign imports and a lower tax credit of $\$ 0.45$, the reduced demand for ethanol will cause the price of ethanol to fall by $\$ 0.11$ per gallon, roughly half of Kruse's calculation. As a result of the price change, the quantity of ethanol produced will decrease by 1.32 billion gallons, in 2012 . Ethanol prices ranged from $\$ 1.45$ to $\$ 2.40$ per gallon, between 2009 through 2011 , with an average of $\$ 1.90$ per gallon (O'Brien 2011). Change in profits from the price reduction will equal the combination of the change in quantity demanded, $\mathbf{1 . 3 2}$ billion gallons, at the new price of ethanol, $\$ 1.79$ per gallon, and the total quantity produced, 13.2 billion gallons, multiplied by the change in the price per gallon. In 2012, producers will lose $\$ 1.5$ billion from the reduced price and $\$ 2.4$ billion from decreased production at the new price, totaling $\$ 3.9$ billion in lost profits. Over ten years, profit loss will equal $\$ 35.5$ billion.

The Renewable Fuels Association, proposed over 100,000 people would lose their jobs, if the VEETC expired, due to reduced demand for ethanol (Urbanchuck 2010). However, based on previously discussed changes in the quantity of ethanol produced, large scale employment changes are not anticipated to occur, since firms have the ability to adjust their production process in the long run.

Farmers will also be impacted by the removal of VEETC due to reduced profits from the decrease in the demand for ethanol by oil producers. This reduction in ethanol demanded will trickle down and cause less corn to be demanded by producers of ethanol resulting in a lower demand for corn. Because corn is the primary ingredient for ethanol in the United States, the cost to farmers can be captured by the loss in profits to corn producers.

In 2010, of the 336 million tons of corn produced, 119.4 million tons went to the production of ethanol fuel (EPI 2011). When the VEETC expires, prices for a bushel of corn are expected to fall by $\$ 0.30$ and corn demanded by ethanol 
producers will decrease by 520 million bushels of corn (Kruse 2007). Projected USDA estimates for corn production for 2012 estimate a total of 12.4 billion bushels of corn will be harvested. The price per bushel is anticipated to be between $\$ 5.80$ and $\$ 6.60$, averaging $\$ 6.20$. With lower demand for corn from the tax credit expiration, farmers will lose $\$ 3.7$ billion from a lower price of corn and $\$ 3.2$ billion from the 520 million bushel decrease in 2012. However, in the long run, through their ability to transition their crops, over five years farmers should be able to return to previous profit levels (USDA 2011). Therefore, farmers will lose an upfront amount of $\$ 6.9$ billion in 2012 and a total of \$20.2 over ten years. Total production costs from the VEETC expiration will equal $\$ 55.7$ billion over ten years.

\section{Consumption}

A majority of gasoline on the market is comprised of 10 percent ethanol. Ethanol blended into gasoline reduces the wholesale price at the pump. In 2011, ethanol was found to be $\$ 0.33$ per gallon cheaper than gasoline, in all regions in the United States (DOE 2011). Decreasing the amount of ethanol being blended will cause the price of gasoline to increase. If an average gallon of gasoline is comprised of ten percent ethanol and the ethanol subsidy is $\$ 0.45$ per gallon of ethanol blended, then the expiration of VEETC will result in a price of gas increasing by an average of $\$ 0.045$ per gallon. The increased price of gasoline will be paid for at the pump, by consumers. In 2010, 138 billion gallons of gasoline was consumed. Assuming gasoline consumption remains constant, the increase in gasoline prices will cost society $\$ 6.2$ billion at the pump in 2012 and $\$ 56.5$ billion from 2012 to 2022.

\section{Environmental}

The total environmental effect of removing the VEETC is difficult to determine. There are conflicting views on whether pure gasoline or ethanol emits fewer greenhouse gases into the environment. The net reduction in greenhouse gas emissions, when comparing gasoline and ethanol during their entire life cycles, from the planting of corn for producing ethanol to burning it as a fuel in automobiles, is highly debated among environmental researchers. The debate is focused on the exact amount of Carbon Dioxide $\left(\mathrm{CO}_{2}\right)$ each part of the life cycle produces, depending on their criteria and assumptions regarding the production of ethanol. In this analysis, both arguments will be presented and addressed here, as well as in the calculating benefits section. The Congressional Budget Office (CBO) compared gasoline and ethanol over their production, distribution, and combustion cycles, assuming that ethanol has been produced by plants and fueled by natural gas. The CBO review took into account the removal of $\mathrm{CO}_{2}$ from the atmosphere when growing corn (CBO 2009). CBO concluded ethanol will create a net of near 20 percent fewer greenhouse gas emissions than gasoline in the short run, translating into approximately 14 million metric tons of carbon dioxide and equivalent gases. The long run continued reduction was found to be unclear. Thus with the VEETC expiration, the reduction of greenhouse gases will be lost. As production of ethanol will only be changing slightly, the anticipated loss in environmental quality from the removal of the tax credit will be negligible.

\section{Summary of Costs}

In total, the cost to society over ten years is $\$ 116.8$ billion. The production of ethanol and harvest of corn are the most impacted areas from the VEETC expiration. As a result, farmers and ethanol producers will experience a loss in profits in the short-term. The profit loss to farmers will increase the demand for federal agriculture assistance. Additionally, citizens will be affected by facing higher gas prices at the pump. Although improved environmental effects were 
Table 3: Costs from VEETC Expiration from 2012-2022 in

Present Value (in billions of US dollars).

\begin{tabular}{|l|l|}
\hline \multicolumn{1}{|c|}{ Group } & \multicolumn{1}{c|}{ Cost } \\
\hline Administrative & $\$ 4.6$ \\
\hline Production & $\$ 55.7$ \\
\hline Consumption & $\$ 56.5$ \\
\hline Environmental & $\$ 0.0$ \\
\hline Total & $\$ 116.8$ \\
\hline
\end{tabular}

desired from ethanol, there does not appear to be a large change in environmental quality without the tax credit.

\section{Calculation of Benefits}

\section{Administrative}

The Internal Revenue Service (IRS) was responsible for processing the VEETC and as a result, receives the direct administrative benefits from its expiration. The total costs of administering a tax credit program are roughly one percent of program expenditures. For VEETC, total expenditures are based on the number of gallons of ethanol blended each year, 13.2 billion gallons in 2012, multiplied by the $\$ 0.45$ credit. With the expiration of the VEETC, the IRS will save \$59 million in administrative costs in 2012 (IRS 2008). Under the status quo, ethanol production will be ten percent above the RFS standards listed in Table 1. Over ten years, the IRS will save $\$ 7.0$ billion.

Ethanol blenders also receive benefits from the expiration of the VEETC in the form of savings from not having to file for the tax credit. In order to obtain the tax credit, oil producers must file forms $637,720,4136,6478$ and 8849 to the IRS, claiming their total volume of ethanol blended with gasoline (IRS 2011). In total, completing all of the forms takes approximately 99 hours: fourteen hours for Form 670, 37 hours for Form 720 and 4136, seven hours for Form 6478, and four hours for Form 8849. Assuming that one employee completes all of the forms at an average salary of $\$ 75,000$ per year, or \$36 per hour, individual oil companies save $\$ 3,600$ in a year (BLS 2011b). With 200 ethanol facilities in the United States, a total of $\$ 72$ million will be saved in 2012. Assuming employees' salaries remain constant, producers will save a total of $\$ 6.6$ billion from 2012 to 2022.

An indirect effect of the VEETC has been rising food prices, which caused increased demand for federal food subsidy programs. The US Department of Agriculture Food and Nutrition Service provide a majority of its food assistance through three programs: Supplemental Nutrition Assistance Program, National School Lunch Program and Special Supplemental Assistance Program Women, Infants, and Children. Between FY 2009 and FY 2010, the USDA spent an additional $\$ 16$ billion on these food assistance programs (USDA 2011). Based on CBO estimates, approximately 10 percent, or $\$ 1.6$ billion, of the increased spending on these programs is a result of higher food prices from ethanol subsidies (CBO 2009). With the growing increase in ethanol production levels and the strain placed on corn to meet this new demand, food prices rose partially as a result of the VEETC. Assuming a constant increase in the price of food, resulting in a 10 percent increase in the annual spending on food assistance programs, removing VEETC will save $\$ 1.6$ billion in 2012. If food prices continue to rise at four percent per year on average, by 2022 taxpayers will have saved $\$ 17.6$ billion in government food assistance programs. The total benefits from eliminating the VEETC in the form of sav- 
ings from the IRS administration of the tax credit, blenders having to fill out paperwork, and federal food and nutrition programs are roughly $\$ 2.2$ billion in 2012 and $\$ 31.2$ billion over ten years.

\section{Consumption}

Beyond administrative savings in the form of decreased price of corn, there are benefits in the form of stabilized food prices. The Impact of Ethanol Use on Food Prices and Greenhouse-Gas Emissions by the $\mathrm{CBO}$ found that the rise in US production of corn accounted for 20 percent of the increase in the price of corn in 2008 (CBO 2009). With the expiration of VEETC, the price of corn will not be artificially inflated.

The increased demand for ethanol to be blended with gasoline caused a ripple effect, consequently raising the price of corn. CBO determined ethanol production accounted for 0.5 to 0.8 percent of the 5.1 percent increase in food prices(2009). Without the VEETC, food prices are expected to stabilize, not rising higher than their 2011 levels all other things being equal; thus causing consumers to spend less money on food, both at the grocery store and at food retail establishments in the long run.

CBO concluded that food expenditure by consumers increased between $\$ 700$ million to $\$ 1.1$ billion in 2007 from a rise in corn prices by $\$ 0.50$ to $\$ 0.80$ (2009). Using a conservative average of $\$ 900$ million and assuming under the status quo that food prices would increase at a rate of four percent over ten years, removing the tax credit would save citizens $\$ 9.4$ billion in 2012 and 10.3 billion in ten years.

\section{Environmental}

A majority of researchers argue that ethanol produces more greenhouse gases than it saves over its lifecycle. In this case, US citizens could receive environmental benefits from the removal of VEETC. CBO estimates that ethanol costs between $\$ 750$ and $\$ 1700$ per metric ton of greenhouse gas emissions reduced by tax credits compared to gasoline over its lifecycle (CBO 2010). Lifecycle greenhouse gas emissions are calculated as the total quantity of greenhouse gases released into the atmosphere during the full fuel cycle, including fuel and feedstock production, distribution, and consumption. The CBO estimate includes the cost of emissions reduced from production and consumption, increases in the energy ethanol requires compared to gasoline, and increases in the federal excise tax on motor fuels from the greater volume of fuel required to supply the same amount of energy. In 2010, 1.7 billion metric tons of $\mathrm{CO}_{2}$ were emitted from transportation sources (EPA 2012, ES4). $\mathrm{CO}_{2}$ represents over 80 percent of the total greenhouse gases emitted by human activity (ES6). At its most efficient, ethanol reduces greenhouse gas emissions by 20 percent. With the expiration of VEETC, production of ethanol will fall to the RFS standard, roughly decreasing by 10 percent. As a result, 34 million metric tons fewer will be released. Using CBO's conservative estimate of $\$ 750$ per metric ton of greenhouse gas emissions removed, citizens will save $\$ 26$ billion in 2012, totaling \$237.3 billion through 2022.

\section{Energy Security}

One of the reasons ethanol subsidies were established was to reduce US dependence on foreign oil. However, many scholars have determined that ethanol is neither truly a renewable nor dependable fuel alternative. Subsequently, ethanol has not significantly reduced US foreign oil reliance. The fossil fuels, such as coal, natural gas, and diesel used in the production of ethanol are greater than the energy savings from burning ethanol. To produce a gallon of ethanol, about 29 percent more energy is required than the total amount of energy in the gallon of ethanol (Pimentel 2003). Since ethanol is produced using nonrenewable fuel, in the process of producing ethanol from corn, ethanol cannot be considered a renewable resource. 
Table 4: Benefits from VEETC Expiration from 2012-2022

in Present Value (in billions of US dollars).

\begin{tabular}{|l|l|}
\hline \multicolumn{1}{|c|}{ Group } & \multicolumn{2}{c|}{ Benefit } \\
\hline Administrative & $\$ 31.2$ \\
\hline Consumption & $\$ 10.3$ \\
\hline Environmental & $\$ 237.3$ \\
\hline Energy Security & $\$ 6.1$ \\
\hline Total & $\$ 284.9$ \\
\hline
\end{tabular}

If all of the corn grown domestically was dedicated to the production of ethanol, only 14 percent of US gasoline consumption would be substituted (Eaves 2007).

Ethanol is not a reliable alternative fuel. Being produced from corn, ethanol is dependent on weather conditions and corn production. Farming is volatile, resulting in federal government providing agricultural assistance during bad seasons. In a good season, a large quantity of ethanol can be produced, allowing for production at a lower cost. However, when limited corn crops are available, ethanol demand will experience a shock, from the increased price of corn creating a higher price for the reduced amount of ethanol produced. As a result, relying on ethanol provides its own risk, different from being dependent on foreign oil.

One key component of energy security is the ability to increase supply when there is a supply disruption, similar to the 1973 or 1979 oil crises. Ethanol cannot meet this need. The capacity or resources to dramatically increase the production of ethanol quickly for a short time do not exist. Without this ability, ethanol cannot secure US energy needs.

The federal government continues to pursue ways to reduce US dependence on nonrenewable fuel. In 2010, the Department of Energy (DOE) was allocated $\$ 672$ million to research and develop new alternatives to phase out the use of fossil fuels (Sargent 2011). The additional funding for alternative fuels demonstrates the inability for ethanol to reduce US dependence on foreign oil and provides an estimate on the value society places on renewable fuel. In 2022, total benefits will be $\$ 6.1$ billion.

\section{Summary of Benefits}

As shown in Table 4, the total benefits received equal $\$ 284.9$ billion from 2012 to 2022. The majority of the benefits from the VEETC expiration come from environmental benefits. Additionally, the termination of administering the tax credit and stabilized food prices will impact consumers as well as reducing the demand for federal welfare assistance.

The net benefits of this policy change are the difference between the benefits and costs. In this case, the result is a positive net present value of $\$ 168.1$ billion. In this assessment, the VEECT expiration impact on energy security and the environment are ambiguous. In order for the VEETC expiration to have a positive net benefit, the combined benefit of energy security and improving the environment must equal \$75.3 billion. Without ethanol being a truly renewable fuel alternative to gasoline and emitting more greenhouse gases over its lifecycle, the threshold is believed to be achievable, making the positive net benefit conclusion highly probable. In addition, this estimate is likely to change due to other factors, which influence the impact of ethanol on society and are discussed in the following section.

\section{Other Considerations}

A number of other factors must be mentioned in this analysis and taken into consideration to understand the full 
impact of removing the VEETC. These issues are beyond the scope of this paper and therefore, will not be monetized or included in this assessment. They are presented as possibilities that could change the outcome of this research. Primarily, innovation will have a significant effect on the results from this study. Increased interest in identifying other alternative renewable fuel options will affect the substitution of gasoline for ethanol that is projected to occur with the expiration of the VEETC. If additional money is invested into the research and development of renewable fuel alternatives, such as electric automobiles or improving the market competitiveness of cellulosic and biofuel ethanol, carbon emissions could be further reduced and the United States will be less dependent on foreign oil. Additionally, as automakers continue to improve the fuel efficiency of automobiles, vehicles will require less fuel to drive the same distance, thus continuing to minimize greenhouse gas emission.

Concurrent to the December 31, 2011, expiration of VEETC, the ethanol import tariff was also terminated. The expiration allows for sugar-based ethanol from Brazil to be exported to the United States without trade barriers. Brazil's ethanol is more fuel efficient and less expensive than its United States corn-based ethanol. Therefore, the importation of ethanol is expected to increase. The total quantity of this increase is dependent on the transportation costs and the demand for ethanol in the United States. As a result, the increase in imported ethanol could put a strain on domestic ethanol producers, thus further reducing their production.

\section{Conclusion}

The expiration of the VEETC is beneficial to society. The majority of costs from this policy change are limited, indirectly effecting input markets. Ethanol producers and farmers are most affected by reduced demand and lower prices for their goods, due to overproduction. The benefits of the VEETC expiration are more far-reaching. Ironically, improvements to the environment and US energy security will experience the greatest benefit from removing the VEETC. The total net present value is $\$ 168.1$ billion over ten years. Through the repetitive relationship between the VEETC and the RFS mandate, the enhanced the inefficiency of the alternative fuel market. VEETC ultimately prohibited alternative fuels from entering the market. The incentive generated by the VEETC encouraged the primary producers of bio fuel to over produce ethanol, rather than explore alternatives. These alternatives have the potential to develop a fuel with greater benefits to the environment and independence from oil. In the future, innovation and increased trade could have significant impacts on this analysis, reducing costs and increasing benefits. As evident, allowing the expiration of VEETC was efficient, and in the best interest of society.

\section{References}

American Coalition for Ethanol. 2012. Accessed April 2. http://www.ethanol.org/index.php? id=37\&parentid=8\#USEthanolFacilities.

Babcock, Bruce, Kanlaya Barr and Miguel Carriguiry. 2010. Costs and Benefits to Taxpayers, Consumers and Producers from Ethanol Policies. Iowa State University, Center for Agricultural and Rural Development. http://www.agmanager. info/about/ contributors/Presentations/Langemeier/Babcock_2010.pdf.

BLS (Bureau of Labor Statistics). 2011a. "Current Population Survey." Accessed December. http:// www.bls.gov/cps.

---. 2011b. National Industry-Specific Occupational Employment and Wage Esti- 
mate: NAICS 211OOO-Oil and Gas Extraction. March http://www.bls.gov/oes/ current/ naics3_21100o.htm.

Central Intelligence Agency. 2011. "The World Factbook.” Accessed December; updated December 2010. https://www.cia.gov/library/publications/the-worldfactbook/.

CBO (Congressional Budget Office). 2009. The Impact of Ethanol Use on Food Prices and Greenhouse-Gas Emissions. http://www.cbo.gov/ftpdocs/10oxx/ doc10057/04-08-Ethanol.pdf.

--_. 2010. Using Biofuel Tax Credits to Achieve Energy and Environment Policy Goals. http://www.cbo.gov/ftpdocs/114xx/ doc11477/07-14-Biofuels.pdf.

DOE (Department of Energy). 2011. Clean Cities Alternative Fuel Price Report. http:// www.afdc.energy. gov/afdc/pdfs/afpr_jan_11.pdf.

Du, Xiaodong, Dermot Hayes and Mindy Baker. 2008. Welfare Analysis of the US Ethanol Subsidy. Iowa State University, Center for Agricultural and Rural Development. http:// ageconsearch.umn.edu/bitstream/44538/2/o8-WP_480_ Revised.11-03.pdf.

EPI (Earth Policy Institute). 2011. Corn Production and Use for Fuel Ethanol in the United States, 1980-2010. http://www.earth-policy.org/data_center/C23.

Eaves, James and Stephen Eaves. 2007. "Is Ethanol the 'Energy Security' Solution?” CATO Institute. http://www.cato.org/publications/commentary/is-ethanolenergy-security-solution.

EPA (Environmental Protection Agency). 2012. DRAFT Inventory of US Greenhouse Gas Emissions and Sinks: 1990-2010. http://www.epa.gov/climatechange/ emissions/downloads12/ Executive\%20Summary.pdf.

Ethanol Across America. 2011. Issue Brief: Economic Impacts of Ethanol Production. 2011th ed. http://www.ne-ethanol.org/pdf/EconomicImpactIssueBrief_2011. pdf.

Gallagher, Paul. 2006. Ethanol Industry Situation and Outlook. Iowa State University. http://www.extension.iastate.edu/ag/GallagherPresent.indd.pdf.

Gardner, Bruce. 2007. "Fuel Ethanol Subsidies and Farm Price Support," Journal of Agricultural \& Food Industrial Organization 5, no. 2; Article 4.

GAO (Government Accountability Office). 2009. Biofuels: Potential Effects and Challenges of Required Increases in Production and Use. http://www.gao.gov/ new.items/do9446.pdf.

IRS (Internal Revenue Service). 2008. Earned Income Tax Credit (EITC) Initiatives: Implementation of Alternative Approaches to Improving the Administration of EITC. http://www.irs.gov/pub/irsutl/poc_summary_addendum_121708_ final.pdf.

-- 2011. Publication 510 - Excise Taxes (Including Fuel Tax Credits and Refunds). July. http://www.irs.gov/pub/irs-pdf/p510.pdf

Kelderman, Eric. 2007. "Ethanol Demand Outgrows Corn.” Stateline.org. http://www. stateline.org/live/details/story?contentId=219881.

Knoll, Keith, Brian West, Wendy Clark, et al. 2009. Effects of Intermediate Ethanol Blends on Legacy Vehicles and Small Non-Road Engines, Report 1 - Updated. National Renewable Energy Laboratory, Golden, Colorado. http://feerc. ornl.gov/pdfs/pub_int_blends_rpt1_updated.pdf.

Koplow, Doug. 2009. "State and federal subsidies to biofuels: magnitude and options for redirection" International Journal of Biotechnology 11, no. 1/2: 92-126

Kruse, John, Patrick Westhoff, Seth Meyer, et al. 2007. "Economic Impacts of Not Extending Biofuel Subsidies.” AgBioForum 10, no 2: 94-103.

McIntyre, Krista. 2011. "EPA Enforcement of the Renewable Fuel Standard.” October. http://www.stoel.com/showarticle.aspx?Show $=8686$. 
O'Brien, Daniel. 2011. "The Impact of Ethanol and Corn Price Trends on Ethanol Profitability." K-State Research and Extension. http://www.agmanager.info/marketing/outlook/newletters/ archives/GRAIN-OUTLOOK_02-05-11.pdf.

Paperwork Reduction Act of 1980. 44 U.S.C 3501. http://www.archives.gov/federalregister/laws/paperwork-reduction/.

Phaneuf, Emile. 2007. US, Brazil Ethanol Industry Comparison - The Economics, History, \& Politics Behind It All. University of Arkansas. http://www.emilephaneuf.com/US-Brazil_Ethanol_Industry_Comparison---Emile_\%2oPhaneuf.pdf.

Pimentel, David.2003. "Ethanol Fuels: Energy Balance, Economics, and Environmental Impacts are Negative.” Natural Resources Research 12, no. 2: 127-134. http://www.college. wustl.edu/ anthro/articles/pimentel-ethanol.pdf.

Sargent Jr., John F. 2011. Federal Research and Development Funding: FY 2011. Congressional Research Service. http://www.fas.org/sgp/crs/misc/R41098.pdf.

Schnepf, Randy and Brent Yacobucci. 2012. Renewable Fuel Standard (RFS): Overview and Issues. Congressional Research Service. http://www.nationalaglawcenter.org/assets/crs/ R40155.pdf.

Urbanchuk, John. 2010. Importance of the VEETC to the US Economy and the Ethanol Industry. Renewable Fuels Association. http://www.ethanol.org/pdf/contentmgmt/VEETC_study_summary_310.pdf.

USDA Food and Nutrition Services. 2011. Annual Summary of Food and Nutrition Services Programs. http://www.fns.usda.gov/pd/annual.htm.

Amy Diggs is pursuing her Master of Public Policy at the Trachtenberg School of Public Policy and Public Administration, focusing on social policy and international affairs. Currently, Amy works at the US Department of State, in the Bureau of Economic and Business Affairs, in the Office of Bilateral Trade Affairs. Amy has previously worked for the Texas House of Representatives and for the National Association of State Budget Officers. She received her BA in economics from Trinity University in San Antonio, Texas.

The author would like to thank Kelly McCoy, Diane Mars, Rachel Brody, and Joshua Nadas for their patience and tireless editing of this paper. She would also like to thank Dr. Stephanie Cellini for her encouragement to pursue this topic, and Dr. Marvin Phaup for his comments and direction on early drafts of this paper. 